\title{
The Bicentenary of Sir Christopher Wren.
}

\section{By Eng.-Capt. Edgar C. Smith, O.B.E., R.N.}

$\mathrm{T}^{\text {но }}$ $\mathrm{GH}$ during the celebration, next week, of the bicentenary of Sir Christopher Wren the main interest must needs centre around his great work as an architect, his position as one of the representative men of science of the seventeenth century should not be overlooked. Five years younger than Boyle, and ten years the senior of Newton, Wren had as his contemporaries Wilkins, Hooke, Goddard, Willis, Sydenham, Flamsteed, and Barrow. The year Wren was born Galileo was writing his famous "Dialogues," and in the subsequent developments which made England the scientific centre of the world Wren was one of the pioneers. While quite a youth Wren joined the group of philosophers who met at the lodgings of Wilkins or Boyle at Oxford, and at twentyfive he became Gresham professor of astronomy. Four years later he returned to Oxford as Savilian professor. The Royal Society owed much to him, and he was one of its earliest presidents. Perhaps not such an extraordinary boy as Young or Hamilton, his genius was recognised from the first. Barrow indeed, in 1662 , referred to him "As one of whom it was doubtful whether he was most to be commended for the divine-felicity of his genius or for the sweet humanity of his disposition-formerly as a boy a prodigy; now as a man a miracle, nay, even something superhuman."

Wren was born at East Knoyle, in Wiltshire, on October 20, 1632 . His grandfather, Francis Wren, was a mercer in the city of London; his father, also Christopher Wren, was rector of East Knoyle and dean of Windsor. Another son of Francis was Matthew Wren, bishop of Hereford, Norwich, and Ely ; a stiffnecked prelate who spent more years in the Tower than he need have done. Wren's mother died when he was young, but his father survived till I658. At nine Wren was sent to Westminster school, then under the famous Busby. From Westminster, after an interval, probably due to the unsettled state of affairsOxford then having more soldiers than students-he passed to the University and was entered as a gentleman commoner of Wadham College, of which Wilkins was the warden. He graduated B.A. in $16_{51}$, M.A. in 1653 , and that year became a fellow of All Souls, holding his fellowship until I66r, the year he was appointed Savilian professor.

Like most students of his day, Wren roamed over many fields of learning. With a talent for fine and accurate drawing he combined a manipulative skill which was the envy even of Hooke. These found employment in many ways. For Willis he made the elaborate drawings for a work on the anatomy of the brain. He was one of the first to inject liquids into the veins of animals. Writing to Petty in 1656 he says, "The most considerable experiment I have made of late is this;--I injected wine and ale into the mass of blood in a living dog, by a vein. ... I am in further pursuit of the experiment, which I take to. be of great concernment, and what will give great light to the theory and practise of physic."

Wren's two professorships cover a period of sixteen years- -657 to $\mathbf{6} 673$. The Gresham and Savilian chairs were the first mathematical and astronomical professorships founded in England. One or the other had been held by Briggs, Bainbridge, Turner, Greaves, Gellibrand, and Gunter. Gresham College, London, was the old mansion of Sir Thomas Gresham, which stood on a site stretching between Bishopsgate Street and Old Broad Street. The lodgings of the professors of music and physic and the Reading Hall were close to Bishopsgate Street, but the quarters of the other professors were situated around a large quadrangle. An interesting sketch of the college is given in Weld's "History of the Royal Society." Wren's appointment was owing to Lawrence Rooke exchanging the chair of astronomy. for that of geometry, the transfer being due "to a conveniency of the lodgings which opened behind the Reading Hall." Wren's lectures were read the same day as Rooke's and attended by the same auditors. He discoursed on telescopes, eclipses, the planet Saturn, and meteorology, and to this period belong his demonstrations concerning cycloids.

In February I66x Wren resigned both his Gresham professorship and his fellowship of All Souls and returned to Oxford to succeed Seth Ward as Savilian astronomer. In this position he continued to investigate a wide range of subjects, suggesting selfregistering weathercocks, thermometers, and raingauges; constructing telescopes for measuring small angles, and making experiments with pendulums. In I668 he showed his experiments to illustrate the laws of motion by the collision of balls. Newton afterwards writing of the laws of motion said: "Dr. Christopher Wren, knight; John Wallis and Christian Huygens, who are beyond comparison the leading geometers of this age, arrived at the laws of the collision and mutual rebound of two bodies; but their truth was proved by Dr. Wren by experiments on suspended balls in the presence of the Royal Society."

It was while Wren still held the Gresham professorship that the Royal Society came into existence. The first official record was a memorandum of November 28 , I660. This gave the names of the persons who had " mett together at Gresham Colledge to heare Mr. Wren's lecture." After the lecture "they did, according to the usual manner, withdrawe for mutuall converse," and it was agreed upon that "this Company would continue their weekly meeting on Wednesday, at 3 of the clock in the tearme time, at Mr. Rooke's chamber at Gresham Colledge; in the vacation, at Mr. Ball's chamber in the Temple." Wilkins was chairman on this occasion. At the next meeting, December 5, Sir Robert Moray, the first elected president, brought word that the King approved of the Society and would be ready to give encouragement to it. The minutes also record that "Mr. Wren be desired to prepare against the next meeting for the Pendulum Experiment." On December i9 Mr. Wren and Dr. Petty were " desired to consider the philosophy of Shipping, and bring in their thoughts to the company about it." 
The Royal Society was further indebted to Wren for drawing up the preamble to the charter of Incorporation in which Charles II. states his determination "to grant our Royal favour, patronage and all due encouragement to this illustrious assembly and so beneficial and laudable an enterprize." The charter was first read on August I3, I662, and two years later Wren gave an address on the objects to which the Society should devote its energies. He exhorts the members " not to flag in the design since, in a few years, at the beginning, it will hardly come to any visible maturity. . . . The Royal Society should plant crabstocks for posterity to graft on." Lord Brouncker became the first president of the Society after its incorporation, Sir Joseph Williamson succeeded him in 1677 , and Wren, who had been knighted in 1673 , was elected president in I680. Boyle had previously declined the honour through " a great tenderness in point of oaths." Wren held office till St. Andrew's Day, r682.

So far, attention has been directed only to Wren's scientific activities. Soon after his return to Oxford, in I66I, he was invited by Charles II. to act as surveyorgeneral of His Majesty's works, and from this time dates his career as an architect, which ultimately raised him to the head of the profession. The first building designed by him was the chapel of Pembroke College, Cambridge, erected by his bishop-uncle as a thank-offering for his liberation from the Tower. His next building was the Sheldonian Theatre at Oxford. In 1665 he spent six months in Paris studying the Louvre and other buildings, returning home, as he said, "with nearly all France upon paper." In I666 came the great fire of London, and with it Wren's opportunity. From September 2 to September 8 the flames swept across the city, and four days later Wren laid a plan for its rebuilding before the King. Immediately afterwards he was appointed "surveyorgeneral and principal architect for rebuilding the whole city; the cathedral Church of St. Paul ; all the parochial churches ... with other public structures." Wren was then but thirty-four, and in the remaining fifty-seven years of his life he not only designed and erected many important private and public buildings, but some fifty London churches, and also his great masterpiece, St. Paul's Cathedral. Several years were occupied in demolishing the ruins of old St. Paul's, and it was not until 1675 , the year Wren built Greenwich Observatory, that the foundation stone of the new cathedral was laid. Thirty-five years later Wren's son put the topmost stone of the lantern into position.

Of the city of London as Wren knew it in his Gresham days but little remains. Wren, if he had had his own way, would have changed its very plan. It was his intention to cut two great arteries from east to west and another from north to south. At the intersections of these thoroughfares would have stood the new St. Paul's and the great public offices. He further designed that a noble quay should flank the Thames from the Tower to the Temple. For better or for worse his plans proved unacceptable, and so to-day it is yet possible to follow some of the footsteps of the old philosophers and to visit their memorials.

Though it escaped the fire, all trace of Gresham's mansion has long since disappeared. St. Helen's Church-sometimes called the Westminster Abbey of the City-where the inmates of Gresham College worshipped, still stands, and within its walls lie the remains of Hooke, Goddard and Gresham. Three of Wren's predecessors in the chair of astronomy, Gellibrand, Foster, and Gunter, were buried in St. Peter le Poer, which stood in Old Broad Street, while Rooke, "the greatest man in England for solid learning," was buried in St. Martin Outwich, from which the monuments were some fifty years ago removed to St. Helen's. Rooke died just before the Royal Society received its charter. Greaves, another Gresham and Savilian astronomer, was buried in St. Benets; John Collins, "the attorney-general of the mathematics," in St. James' Church, near Southwark Bridge, while John Wilkins, first secretary of the Royal Society, and from I668 bishop of Chester, who died in I672, was buried in St. Laurence Jewry. This was one of the churches rebuilt by Wren. Wilkins had been rector of the church, and on one occasion he invited Barrow to occupy the pulpit. Barrow preached so well that Richard Baxter declared he "could willingly have been his auditor all day long."

Wren himself lies in the crypt under the south aisle of the choir of St. Paul's. He died on February 25, I723, and was buried on March 5. The well-known quotation from his epitaph: " $\mathrm{Si}$ monumentum requiris, circumspice," now to be seen over the north door of the cathedral, was first carved on the choir screen by Robert Mylne, the builder of the first Southwark Bridge and surveyor of St. Paul's, who lies close to Wren in the crypt.

The grand committee formed by the Royal Institute of British Architects and other bodies interested, to celebrate the bicentenary of the death of Sir Christopher Wren, has arranged for a public commemoration service in St. Paul's Cathedral, on Monday, February 26, at 2.30 P.M., in the course of which an address will be delivered by the Very Rev. W. R. Inge, Dean of St. Paul's. The members of the grand committee, accompanied by the Lord Mayor and Sheriffs, will proceed afterwards to the crypt, where Mr. Paul Waterhouse, president of the Royal Institute of British Architects, and an attaché from the American Embassy in London, on behalf of the Architectural League of New York, will lay wreaths upon the tomb of Sir Christopher Wren. In the evening a Christopher Wren commemoration banquet will be given by the Royal Institute of British Architects at the Hotel Victoria, Northumberland Avenue, and commemorative addresses, dealing with the life and work of Wren, will be delivered.

In addition to these celebrations there will be exhibitions illustrating Wren's work, at the Galleries of the Royal Institute of British Architects, 9 Conduit Street, W.I, on February 26-March 3, and at the Museum, Public Record Office, Chancery Lane, W.C.2, both of which will be open free of charge to the public.

Another interesting proof from overseas of regard for the memory of the great London architect comes from the Architectural Institute of British Columbia, which has arranged to hold, in the largest Anglican church in Vancouver, a memorial service on exactly similar lines to the service which will be held in St. Paul's Cathedral on February 26.

NO. 2782 , vOL. I I I ] 